\title{
INFORMAL EDUCATION OF SPECIALISTS WORKING WITH AT-RISK TEENAGERS AT THE FACILITY OF THE "COMPASS" DAY CENTER OF THE KHARKIV CHARITY FOUNDATION "BLAGO"
}

\author{
O. Mohylka, M. Tkachenko
}

\begin{abstract}
У статті розкрито проблему безперервної підготовки фахівиів до роботи з підлітками групи ризику, зростання кількості яких в Україні зумовлено, зокрема, збільщенням сочіальних ризиків, щуо спричинені соціально-економічною нестабільністю в країні, неконтрольованим переміщенням населення на тлі відсутності дієвих механізмів регулювання міграційних процесів на користь національного розвитку, високим рівнем зовнішньої трудової міграції дорослого населення, зниженням педагогічного потенціалу сім'ї та інших соиіальних інститутів; оприлюднено розроблену та впроваджену на базі центру денного перебування «Компас» Харківського Благодійного фонду «Благо» систему організаційно-методичного $і$ ресурсного забезпечення підготовки спеціалістів з надання якісних та своєчасних послуг підліткам споживачам наркотиків.
\end{abstract}

Мета статті є показати ефективність використання сучасних форм підвищення кваліфікації фахівців служби ювенальної пробації, ювенальної превениії, шкільних офіцерів поліції, педагогічних працівників та фахівців соціально-педагогічної служби навчальних закладів на прикладі підготовки фахівиів до роботи з підлітками групи ризику на базі иентру денного перебування «Компас» Харківського Благодійного фонду «Благо». Говорячи про підвищення кваліфікації авторський колектив має на увазі не юридичний термін, а підвищення рівня знань, умінь та навичок в роботі з підлітками групи ризику тих фахівців, які займаються виховною, превентивною діяльністю або здійснюють соиіальний супровід підлітків, які опинилися в складних життєвих обставинах. Акцентовано, щзо створення подібної гнучкої й чутливої до соціальних запитів системи освіти протягом життя здатне не лише забезпечити підвищення кваліфікації фахівців, які праџюють у проблемі, а й дієво сприяти залученню до роботи з підлітками групи ризику не повністю задіяних у трудовій сфері груп населення (безробітних, людей похилого віку, студентську молодь, самих підлітків), підготовити їх до розробки і впровадження нових соиіальних $i$ освітніх проектів, спрямованих на підготовку неповнолітніх до життя в умовах глобалізачії та наростання міграчій, надання їм зразків неконфліктної, впорядкованої й безпечної для суспільства поведінки.

Запропоноване дослідження дозволяє вирішувати питання зменшення наслідків трудової міграції населення України в аспекті зменшення рівня сочіального сирітства, компенсації педагогічного впливу, якого бракує підліткам групи ризику, щуо залишаються без належного батьківського догляду, часто саме в наслідок поширення явища трудової міграџії.

Розробка теоретичних аспектів такої форми підвищення педагогічного потенціалу фахівців, сприятиме розширенню можливостей фахівців правоохоронних органів $i$ сочіальної сфери, служби пробації, сочіально-психологічної служби закладів освіти з формування у підлітків навичок безпечної поведінки для збереження їх сексуально-репродуктивного здоров'я й особистісного потенціалу. У майбутньому изе впливатиме на формування мотивації у підлітків на подальше професійне становлення, самореалізацію їх в Украӥні $i$, як наслідок - на стан національного ринку праці, забезпечуючи збереження потенціалу кваліфікованих працівників

Ключові слова: підвищення кваліфікаџіï, ресурсний цеентр, підлітки, профілактика, ризикована поведінка, зменшення шкоди

Copyright (C) 2020, O. Mohylka, M. Tkachenko. This is an open access article under the CC BY license (http://creativecommons.org/licenses/by/4.0).

\section{Introduction}

A repressive approach in working with offenders, drug users have proven their effectiveness not in the modern world. In this context, particularly important is the interaction of non-governmental organizations, working with vulnerable populations, and law enforcement and probation services. Mostly teenagers, who come to the attention of the police or are already registered in the probation service, have a set of risks, which can seriously affect their health and the opportunity to full selfrealization. We are talking about the consumption of psychoactive substances, unprotected sex, situations of conflict, caused by intoxication or demand for money or other offenses.

In the conditions of increasing social risks, increasing socio-economic instability, the continued military conflict in the East of the country, uncontrolled population movements in the absence of effective mecha- 
nisms of regulation of migration processes in the interests of national development and a high level of external labor migration of the adult population for the modern experts of the social sphere, there are new challenges that require the continuous improvement of a level of readiness to the solution of social problems. The orientation and content of social work are determined now by the need to resolve issues, associated with the predominance of negative demographic and immigration processes, ensuring not only a quantitative decrease in the population of the country, but also the decline in living standards, destruction of the family institution, the escalation of child abandonment and child neglect, the spread of dangerous diseases and the rapid increase in the mortality rate of certain social groups, including among children and youth.

Demographic deprivation in Ukraine is connected with labor migration, which is voluntary and, as noted in the literature, motivated by the desire of an individual to obtain a better paying job, to improve living conditions and social position, and forced migration, which is caused by military, political events, persecution on ethnic and religious basis, which force people to relocate [1].

Along with this, we note that Ukraine occupies one of the first places in Eastern Europe and Central Asia in terms of the spread of dangerous diseases, primarily HIV infection among key populations. UNAIDS touches gay men and other men who have sex with men, sex workers, transgender, people who inject drugs, prisoners and persons in custody as the main five key populations that are particularly vulnerable to HIV and frequently lack the adequate access to services [2].

Particularly vulnerable groups include adolescents, who are beginning to practice risky behaviors, while under the specter of child neglect and homelessness, the driving force behind which are the deterioration of material well-being for a significant portion of the population, unemployment of parents, the search for occupations in other countries, the decline of parental responsibility for the upbringing of children, conflict between parents and children and the like. Under the influence of adverse socio-pedagogical factors the rapidly growing number of adolescent drug users can be observed. And although the current drug scene in Ukraine is saturated with a large number of drugs, the probability of infection of socially dangerous diseases for teenagers is large enough, since often the infection is sexually transmitted.

According to the results of a study, conducted in 2018 among adolescent drug users in 32 settlements with a population less than 100 thousand people from 7 regions of Ukraine, among the interviewed girls under the age of 19 years, $42.6 \%$ had casual sex partners in the last year, whereas among boys, $65.4 \%$. To the question regarding the use of a condom by their partners during the last sexual contact, sad 23.8 percent of respondents reported "no", and $5.6 \%$ did not remember or did not know if they have used a condom [3]. Such data can indicate a high risk of sexually transmitted infections among adolescents. A characteristic of adolescents is the presence of several sexual partners. False information or lack of knowledge of sexual and reproductive health, modes of transmission of HIV or other diseases, increases myths and misunderstandings of the consequences of drug use and contraception.

From the prior experience with teenagers, it can be noted, that a significant number of parents talk to their children about sex, drugs, and contraception. Some of the information teenagers receive are from friends or from the Internet. Today, specialists of social sphere, particularly in the day center, become more than powerful agents of social education of adolescents at risk. In view of this pressing matter is the need to organize the flow of quality information from specialists, who have a direct contact with adolescents at risk. Another problem is the knowledge of such professionals that are of interest to adolescents and the ability to convey to them this knowledge in forms that can contribute to the formation of self-motivation in adolescents to abandon a risky behavior.

Ukraine moves to international standards of provision, including preventive services and has responsibilities for implementing the experience of foreign countries on strengthening legal protection in childhood, in the implementation of the main provisions of international and national regulatory legislation, concerning the respect for human dignity and non-discrimination of persons, irrespective of the presence or absence of his/her discriminatory grounds. Some manifestations of discrimination are a violation of the rights of vulnerable groups, namely adolescents, who are in difficult life circumstances, and show a risky behavior.

The "Compass" Day Care Center of Kharkiv Charitable Foundation "Blago" works with adolescents, who have the experience of drug use and other forms of a risky behavior, including being in conflict with the law, aimed at reducing the harm from the consequences of such behavior for the individual and society. This activity is oriented both to work with the teens themselves and with their environment. Because the adolescent's referral system of service providers provides a clear understanding of his or her individual needs, the problems, faced by adolescents, and the perception of a rather innovative harm reduction philosophy in Ukraine; this puts appropriate requirements to the training of professionals.

The continuing education system is designed to create opportunities to fill the gaps in the knowledge of professionals, involved in working with at-risk adolescents, by empowering them by participating in internships, webinars, trainings and other innovative forms of gaining new knowledge and skills.

\section{Literature review}

In modern scientific literature some aspects of the problems of socio-pedagogical work with persons with a risky behavior has been well studied. Factors that bind the way of life and the likelihood of HIV infection have been clearly identified. In Ukraine newsletters with information about the status of HIV infection are regularly published [4]. At the end of the last century, the country began to actively discuss and implement harm reduction programs, which are mainly implemented by non-state organizations. A scientific substantiation of the effectiveness of such programs began to appear and to form the public opinion about the liberalization of drug policy. 
The program of work with teenagers, using the strategy of relying on strengths-oriented decision approach, techniques, motivational interviewing, narrative practices in work with a case and the like are gaining popularity, though still rather innovative and unique in Ukraine. Unfortunately for Ukrainian language, books and textbooks on the theory of social work, based on strengths, as well as new approaches and methods of work with this category of persons has not yet been translated.

In foreign publications, the strategy of relying on strengths in working with children at risk, which was based on an optimistic perception of the previous social experiences of a teenager and opportunities of changes, is already quite developed. Some of the journals that cite the strategy are translated into Russian language [5]. Among these publications attention must be paid to the Russian-speaking practical guide, based on the experience of working with injecting drug users in the framework of the strategy of harm reduction [6], practical publication, which deals with the basics of using the technology of motivating interviewing of drug users, began to be implemented in Ukraine with the assistance of the International Alliance on HIV in Ukraine and ICF “AIDS Foundation East - West" [7].

Unfortunately, there are not many organizations in Ukraine that would conduct certified trainings on popular methods of working with at-risk adolescents, including motivational interviews, in various countries; this explains the lack of relevant Ukrainian-language literature.

Among the English-language literature there should be highlighted the work of psychologists, who have studied the formation of an adolescent personality under the influence of various factors, as well as dedicated to the technology of promoting positive changes in the development of a personality with the use of own resources and techniques, oriented to a decision [8,9].

Noteworthy are the developments, aimed at using a decision-oriented approach in the social support of families in difficult life circumstances, as well as narrative practices in casework $[10,11]$.

The science has developed different approaches to the periodization of adolescence, describes the characteristic patterns of behavior and the reasons that cause them. Risk factors for adolescent behavior disorders have been investigated $[12,13]$ and it has been found, that adolescents, subject to the same risk factors (parental alcoholism, poverty, violence), may exhibit different, not necessarily negative, behaviors. The pedagogical literature substantiates strategies for overcoming the risks, associated with the factors, affecting the adolescent's personality formation, based on the fact that the teenager's viability is influenced by: the presence of loved ones, a supportive social environment, positive self-esteem, problem-solving skills, and feelings [14].

We are increasingly seeing the term "teens" in domestic state and regional targeted programs, including those that involve the implementation of a drug policy strategy. For example, in the Comprehensive Program on Combating Drug Addiction and Reduction of the Harm from the Use of Psychoactive Substances in the Pure City in 2019-2020, the term "adolescents" is used along with the terms "children", "youth" [15]. And if the national legislation clearly defines the concept of "children" or "youth", the concept of "teenager" is, so to speak, not legal.

On the other hand, professionals are trained to work with harm reduction programs that include, apart from syringe exchange, condom distribution, anonymous rapid test testing, counseling on risk behaviors, so oriented to interact with adult drug users, sex businesses and men having sex with men; while the preparation of atrisk adolescents is largely neglected. This reduces the possibility of detecting diseases among adolescents and conducting high-quality prevention of a risky behavior.

There are positive developments in the training and activities of risk prevention professionals. In some cities of Ukraine, the project "School Police Officer" has started, with the aim of creating the perception of police officers as mentors in the student environment. The project envisages the implementation of the School and Police program. The program consists of six topics for students of 1-5 grades and 18 topics for students of 6-11 grades. Among the topics that are designed to protect the life of a student is the topic of drugs. But, for the most part, it is considered in terms of the law - the responsibility for the illicit distribution, possession and use of drugs. It should be noted, that most of those psychoactive substances, used by adolescents, are not legally drugs.

In 2012, the educational and preventive program of training sessions "Steps" was released. It is a teaching and guidance tool for social educators, social workers, outreach workers, practicing psychologists on HIV prevention, drug addiction, sexually transmitted infections and risky behaviors. The guide summarizes the experience of implementing HIV prevention projects and programs among homeless adolescents by Health Right International in Ukraine and Russia. The manual is addressed to professionals, working in the field of prevention of a risky behavior among children and young people [16].

In 2014, with the financial support of the United Nations Office on Drugs and Crime (UNODC), a methodological guide, Drug Prevention among Student Youth, was developed for organizers of the educational and preventive work to prevent and combat the psychoactive substance use among students. The guide is designed for social educators and social workers, psychologists in vocational schools and higher education institutions, centers for social services for families, children and youth, community organizations, as well as student self-government leaders, who organize the preventative work with peers in their educational institutions [17].

Since 2000, within the framework of the Ministry of Education and Science of Ukraine / APS of Ukraine / UNDP in Ukraine / UNAIDS, the concept of peer-to-peer education on healthy lifestyles among young people of Ukraine has been developed. The implementation of the objectives of this program involves the formation of healthy lifestyles of students, creating and providing conditions for the prevention of drug addiction, HIV / AIDS, sexually transmitted infections among young people, raising the level of awareness of adolescents and young people about health, healthy way of life, the formation of their respective values and crucial believes. The concept of such peer-to-peer education is 
the preparation of adolescent instructors and their involvement in the educational work on healthy lifestyles among peers [2].

However, in our time, when there are almost every day new drugs which have different effects on the mental and physiological status of adolescents, it is necessary for there to be a rapid response to these changes and invent new approaches in the prevention work, to overcome addiction, reduce the harm with regard to the requirements of the present in providing objective information to adolescents that covers all the important informational topics. So, the work with specialists and volunteers, who assist children at risk, must be based on innovative approaches, new information, newly invented technologies. The introduction of such training today is an unfilled niche in the education system and the state in this issue lays a lot of hopes on the public sector.

Merit and regional projects for training social workers are the Sirs in the prevention and overcoming of violence and discrimination. Among them is an innovative project "Gender open University: gender, literacy, and culture for social workers", reigning in the city of Kharkiv and Kharkiv region from 2017 The main course of the project of implementation of specialists of the social sphere is a gender neutral approach in terms of concepts and the search for new forms of professional interaction in the system "the social worker - client - territorial community". The training modules covered issues such as: gender neutral practice of professionals and volunteers in social and socio-legal spheres; gender equality approach to the organization of the work of a probation officer; the work of employees of the probation of modern family and community as the cells of gender socialization of a personality, etc [18].

Reforms of the education system, social services, law enforcement institutions, medical, educational and social assistance for vulnerable adolescents, public sector require better access to on-going educations for professionals, aimed at providing new knowledge and modern competencies. Skills of professionals should reflect current challenges and demands.

The proposed study is capable of contributing to the reduction of social orphanage as a result of the pedagogical neglect of children, whose parents are abroad. The development of theoretical aspects of information forms of increasing the pedagogical potential of professionals, working with this category of adolescents, will contribute to the practical application of the approach of reducing the harms of the consequences of risky behaviors of adolescents and increasing the potential of youth in the system of social reproduction.

In addition, it should be noted, that, for the most part, adolescents, who practice a risky behavior, are students of vocationally-oriented educational institutions future professionals in the working professions. Today's labor market requires employees with not only deep knowledge and skills in the field of expertise, but also a diversity of views, the ability to adapt to new conditions and to navigate well in social norms and relationships.

The competitiveness of a modern specialist is determined not only by their professional knowledge and skills, but also by their state of health and ability to withstand a considerable physical and psychological stress. If a young professional does not respond to the employer, he or she is forced to either seek employment outside the country or find other ways to earn an income - sometimes not always legitimate. Thus, the informal training of professionals, working with at-risk adolescents, will influence the formation of a motivation in adolescents to maintain their health as one of components of the professional capacity, which will affect the state of the labor market in Ukraine and, in the future, renewal of the potential of skilled workers.

\section{The purpose and objectives of the study}

The aim of the study is to substantiate and especially to develop a system of organizational-methodical and resource support for the training of specialists to provide quality and timely services to adolescents - drug users.

To achieve the goal, you must accomplish the following tasks:

1. To develop programs for the different forms of training (training, internships, practice, exchange of experience);

2. To organize training on the basis of the day center and in partner organizations;

3. To develop and train specialists to apply effective tools for the prevention of risky behaviors of teenagers;

4. To conduct a survey of knowledge of professionals on the main issues on the topics of the sessions before and after training.

5. To involve specialists of partner organizations for the joint implementation of preventive interventions among the high risk youth.

\section{Materials and methods}

In the research process, methods of testing, questionnaires, observation, pedagogical experiment helped us to study the level of knowledge of experts on issues, related to preservation of sexual and reproductive health of adolescents and protection of their rights and prevention of negative phenomena among adolescents, among professionals, working with adolescents at risk, namely specialists of juvenile probation, juvenile prevention, school police officers, social workers, psychologists, workers of vocational education and experts of the level of primary health care. The methods of modeling and design of a program training course at training specialists to work with children at risk were used.

\section{Results of the study and their discussion}

From the beginning of 2018, the Resource Center began operating at the Compass Day Care Center, which aims to promote the development and implementation of innovative methods of organizing an educational process, aimed at preventing the risky behavior of adolescents and improving the professional competence of professionals in the educational, social, medical, spheres and law enforcement organs in the direction of primary, secondary prevention of the adolescent psychoactive substance use.

The following didactic materials are used in the resource center for reducing the harm from the consequences of adolescent risky behaviors:

1. A curriculum on harm reduction from consequences of a risky behavior of teenagers (own development of Compass CDP); 
2. A workbook for training sessions on the program to reduce the harm from the consequences of risky behaviors of adolescents (own development of Compass CDP);

3. A board game "Drugs? Not my topic!" (Own development by Compass);

4. An interactive game "Teenager on the wrong side" (own development of CDP "Compass");

5. An interactive Safety Route Game (developed and produced with the assistance of GIZ)

6. QR Code Assistant to Restore My Rights (own development by Compass, recognized as the best practice of youth work in Ukraine in 2019).

Apply also other means and tools.

The resource centre operates in three areas:

1. Organizational-methodical:

- compilation and analysis of the organization of prevention of a risk behavior in schools;

- development and implementation of information and methodical materials, tools for the implementation of quality prevention among high risk youth;

- introduction of new forms of work with teenagers, with the latest positive trends in Ukraine, aimed at prevention of negative consequences of a risky behavior;

- research on the illicit use of psychoactive substances by teenagers, materials for the risky behavior prevention, the quality and adequacy of services, provided to adolescents-drug users, gender characteristics and the like.

2. Training:

It includes the conduct of training workshops, seminars, training for professionals, working with adolescents, in particular, prone to a risky behavior.

Training is carried out on the program to reduce the harm from the consequences of a risky behavior of teenagers, which consists of 3 training modules [19]:

- "Prevention of occurrence of deviations in the health of adolescents";

- "Protection of the rights of children and young people, prone to a risky behavior";

- "Formation of a socially active position in life of teenagers of "risk"

3 . The direction of practical training, arranging and conducting educational, industrial and other types of practical training of students, studying for the professions, involving the work with children at risk (social workers, psychologists, medical workers, law enforcement officers and the like).

The internship program provides 72 hours of practical training in risk-averse adolescent groups, training for trainees on topics, related to working with at-risk adolescents, and performing self-directed tasks.

On the Compass Day Center Facebook page, an ad is posted about the recruitment of students for the internship, and after the group recruitment, during their free time students go to practice, where they develop skills for working with at-risk adolescents.

So, in 2019, six students, future social workers, law enforcement specialists and psychologists passed the practice by their own free will under the resource center program. Five professionals have been trained to improve their skills in the prevention of adolescent risky behaviors. Among the specialists, who have received internships, are representatives of the juvenile probation service, juvenile prevention, psychologists and social teachers of vocational education institutions.

An important area of the resource center activity is to provide educational trainings, which focus on information about how to reduce the harm from the drug use among adolescents. Before each training participants are invited to complete a questionnaire to find out the level of knowledge of the main issues of the training session at the beginning. At the end, another questionnaire is filled in with similar questions to see if the level of knowledge has increased after the class.

For example, on September 18, 2019, the training was held for health workers on the topic: "Prevention of HIV / AIDS and viral hepatitis among adolescents at the level of primary health care in Ukraine." The training was attended by: a teenage doctor -1 , a medical doctor from the student hospital - 1; nurses and paramedics of vocational schools -8 specialists.

During the training, an entrance / exit test of knowledge was conducted. Participants were asked general questions about HIV / AIDS, how to transmit infection and prevent the risk of the disease, questions about providing HIV counseling and testing services. Each participant had to answer 13 questions. A total of 130 responses were received. The analysis of the results showed that the largest number of incorrect answers came to general questions. For example, only $50 \%$ of participants answered "Which cells of the human body are sensitive to HIV?" Only $30 \%$ of respondents were able to determine the stage of HIV infection in Ukraine. Only half of the respondents were able to identify contingents, belonging to high-risk groups for HIV infection. The input testing result: correct answers - $63(48 \%)$; incorrect answers $41(32 \%)$; incomplete answers - $26(20 \%)$.

According to the results of the final testing, participants learned the knowledge of issues that had had gaps in pre-testing. Namely: correct answers - 121 (93\%); incorrect answers - 0; incomplete answers $9(7 \%)$. Thus, the training participants showed a $45 \%$ improvement in their level of knowledge.

During the interviews respondents expressed gratitude for the relevance of topics selected and informational content of the training. The participants noted that their activities will be directed including on the Advisory work with Teens on prevention of HIV through the initiative of medical workers and will focus on the motivation of adolescents, regarding the establishment of their own HIV status. There was also announced the desire for organization and conduct of such trainings for health workers, in particular, on the topic of prevention of the drug abuse among adolescents

On November 27, 2019 the training was held for teachers of bases of health on the theme: "Actual issues of HIV/AIDS prevention among youth". The training was attended by 13 school health teachers from the Holodnogirskyi district, Kharkiv city.

The training was conducted by the input/ output test control of knowledge. Participants were given General questions on HIV/AIDS, ways of transmission and prevention of risks of destruction, questions on HIV testing. Each participant must answer 7 questions. There were 91 responses. The analysis of the results showed that $92 \%$ of participants know the ways of HIV trans- 
mission; all participants correctly determine biological substances, in which there is the greatest amount of virus in HIV+; but only $23 \%$ of the participants correctly determined the HIV-sensitive cells of the human body. Only a third of respondents designated contributors, belonging to high-risk groups, regarding HIV infection. That means $38 \%$ of the respondents understand the negative/positive HIV test result correctly. The result of the entrance test: the correct answer is 41 (45\%); wrong answers - 26 $(28,5 \%)$; incomplete responses - 24 (26.5\%).

According to the results of the final testing, participants learned the knowledge of issues that had had gaps in pre-testing. Namely: correct answers - 74 (81.3\%); incorrect answers - 3 (3.2\%); incomplete answers $11(12 \%)$. Thus, the training participants showed a $36 \%$ improvement in their level of knowledge.

Reflection confirmed the expectations of the trainees that they received during the training. They were grateful for the relevance of the materials, methods and exercises that they, as health teachers, could now use in their daily work on HIV prevention among the student youth. Participants of the training expressed their wish to participate in similar trainings on the prevention of viral hepatitis and sexually transmitted infections.

The analysis of the pre- and post-training questionnaires for the training of "Influencing factors on adolescent personality formation" for school police officers:

There are 14 participants in total.

Results of the pre-training questionnaires show that $85.7 \%$ of training participants disclosed the concept of "risk group". Only $35.7 \%$ gave the correct answer to the question on what influences child's development and listed the close surrounding of children and their social roles. The strategies for influencing the teenager behavior were listed by $55.7 \%$ of the training participants.

After the final questionnaires were processed, we have the following results: $95.7 \%$ of participants disclosed the concept of risk group; $65.7 \%$ described the agents that influences child's development and listed the leading activity of a child according to age. However, there are also allegations of social roles and immediate surroundings. Participants in the oral survey indicated that they had had only superficial knowledge of age psychology when studying. However, they noted that such knowledge is essential for practical work. $85.7 \%$ of participants named risk management strategies.

We also note that all participants expressed a desire to undergo similar training at Compass CSD to deepen their knowledge of psychology, practical work with at-risk adolescents and establish their first contact with a child for anamnesis.

The themes of these sessions were proposed by the preliminary requests of participants.

In this case, it should be noted, that in contrast to the school teachers of the subject basics of health and health workers, school police officers are trained under the supervision of the day center "Compass" not for the first time. On this basis, we can assume that the best results of the input survey is the result of systematic work on improving the level of knowledge among professionals on topics, related to the peculiarities of working with adolescents at risk.
Of course, one can hardly argue that this experiment can $100 \%$ confirm the hypothesis that the work of the resource centre for professionals, working with adolescents at risk, can seriously affect the implementation of harm reduction programs for adolescent drug users. But within one region, a noticeable improvement of cooperation between different providers of services to children at risk, is manifested in the institutions of probation, Department of juvenile prevention and school police officers, the organization of the direction of teenagers from school to the day care centre "Compass" for the passage programs, in accordance with the request of a teenager, or problems, which led to a risky behavior.

In September 2019, the experience of the day centre "Compass" of Kharkiv charitable Foundation "Blago", working with adolescents at risk and professionals, working with these adolescents, was presented at the meeting of the coordinating Council on drug policy at the Kharkiv city Council, and the work with adolescent drug users has become a part of the municipal program "Clean city".

\section{Conclusions}

In general, during the study we came to the following conclusions:

1. The level of training of at-risk professionals is insufficient and it is necessary to implement continuing education programs directly in the centers, where adolescents work. The Compass Center annually includes more than 200 teenagers in social support programs, where they receive a package of services in accordance with the standards, adopted under the project "Rights and Health of Vulnerable Populations: Filling the Gaps", with about 500 more teenagers in Kharkiv and four cities of Kharkiv region are counseled on the consequences of a risky behavior and are able to find out their HIV status.

A training program for reducing the harm from the consequences of a risky behavior of adolescents was developed and tested on the basis of the Compass day care center of Kharkiv Charitable Foundation "Blago", aimed at improving the skills of probation officers, juvenile prevention, patrol police and social workers in matters of formation of behavior, unrelated to the risks to life and health, as well as the involvement and training of others from the local community and directly from the adolescent environment.

2. A training program has been organized at the day care center and partner organizations since 2019 to provide knowledge on age and psychological characteristics of at-risk adolescents for 72 hours. The training was conducted according to modern activating forms of work (trainings, internships, webinars, interactive games, consulting with specialists, workshops, etc.).

3. During the training, the specialists have learned innovative skills of owning and using in the work effective tools for prevention of a risky behavior of adolescents (board games, preventive quests, web quests, information materials developed by teenagers, etc.).

4. About 50 specialists were trained in the Compass resource center programs.

A special monitoring and diagnostic toolkit (entrance and exit questionnaires, interview questions and focus groups on the learning outcomes) was developed to 
study the effectiveness of the training course. The results of the survey on the level of knowledge of the specialists in the basic questions on the topics of classes before and after the study showed that, on average, there was an improvement of knowledge of more than $30 \%$. We hope that these experts will be able to speak candidly and professionally with children on various "uncomfortable" topics in an interesting form and this will be their contribution to the fight against drug and HIV infection in our city, in our country.

5. Specialists of such partner organizations are involved in joint prevention activities among teenagers of risk groups: patrol police, juvenile prevention, institu- tions of vocational education system, medical institutions, youth centers of Kharkiv and Kharkiv region.

To date, funding for harm reduction programs for adolescents exclusively by foreign donors is a significant challenge in the field of harm reduction training, based on a harm reduction philosophy. That is why such models work only in some regions of Ukraine. Instead, it is hoped that the results of this engagement will encourage state and local governments to develop resource centers and support harm reduction programs for at-risk adolescents. This is especially true in the case of young people, who are in demand in the labor market, especially in Ukraine and in the countries of the European Union.

\section{References}

1. Lykhovid N. O. Doslidzhennia naslidkiv ta efektiv mihratsiinykh protsesiv Ukrainy // Derzhavne upravlinnia: udoskonalennia ta rozvytok. 2017. Issue 4. URL: http://nbuv.gov.ua/UJRN/Duur_2017_4_6

2. Kliuchevye gruppy naseleniia. URL: https://www.unaids.org/ru/topic/key-populations (Last accessed: 09.12.2019)

3. Analitychnyi zvit za rezultatamy doslidzhennia v ramkakh proektu «Pidlitky poza uvahoiu: polipshennia dostupu do VILservisnykh posluh dlia vrazlyvykh pidlitkiv v Ukraini» / Balakirieva O. M., Shevchenko S. L. et. al. Kyiv: MBF «Alians hromadskoho zdorovia», MBF «SNID Fond Skhid-Zakhid» (AFEW-Ukraina), 2019. 60 p.

4. Antonenko Zh., Kuzin I., Martsynovska V. VIL-infektsiia v Ukraini: Informatsiinyi biuleten No. 50 / ed. by Kurpity V. Kyiv, 2019. 109 p.

5. Malkolm Pein Sotsyalnaia rabota: sovremennaia teoryia: textbook / ed. by Kamplynha Dzh. Moscow: Akademyia, 2007. 400 p.

6. Pavlovskyi A. Sotsyalnaia rabota s podrostkamy s oporoi na sylne storoni: textbook. Kyiv, 2015. 108 p.

7. Motyvatsyonnoe interviuyrovanye lyts, upotrebliaiushchykh inektsyonnie narkotiki: textbook. Kyiv, 2004. $108 \mathrm{p}$

8. Saleebey D. Strengths Perspective in Social Work Practice, 4/e. Toronto: Allyn and Bacon, 2002. 220 p.

9. Miller W. R., Rollnik S. Motivational Interview: helping people change. The Guilford Press, 2013. 482 p.

10. Berg I. K. Family Based Services: a solution-based approach. New York: W. W. Norton \& Company, 1994. 240 p. URL: https://www.amazon.com/Family-Based-Services-Solution-Based-Professional/dp/039370162X (Last accessed: 15.01.2020)

11. Paquin G. W. Clinical Social Work: a narrative approach. Kindle Edition, 2013. 380 p. URL: https://www.goodreads.com/book/show/22174837-clinical-social-work

12. Garmezy N. Stress-Resistant Children: The Search for Protective Factors // Journal of Child Psychology and Psychiatry Book Supplement. 1983. Issue 4. P. 213-233.

13. Rutter, M. (1987). Psychosocial resilience and protective mechanisms. American Journal of Orthopsychiatry, 57 (3), $316-$ 331. doi: http://doi.org/10.1111/j.1939-0025.1987.tb03541.x

14. Masten, A. S., Powell, J. L. (2003). A Resilience Framework for Research, Policy, and Practice. Resilience and Vulnerability. Cambridge University Press, 1-26. doi: http://doi.org/10.1017/cbo9780511615788.003

15. Kompleksna prohrama z protydii poshyrenniu narkomanii ta zmenshennia shkody vid vzhyvannia psykhoaktyvnykh rechovyn u m. Kharkovi «Chyste misto» na 2019-2020 roky: Kharkivska miska rada No. 1717/19. 21.08.2019. URL: http://kharkiv.rocks/reestr/680256 (Last accessed: 09.12.2019)

16. Ckhodynky do zdorovia: prosvitnytsko-profilaktychna prohrama treninhovykh zaniat z uchniamy navchalnykh zakladiv systemy zahalnoi serednoi osvity / Brusenko O. L., Zhuravel T. V., Liakh T. L. et. al.; ed. by Zhuravel T. V., Liakh T. L. Kyiv: Vydavnychyi dim «Kalyta», 2012. 232 p.

17. Profilaktyka vzhyvannia narkotykiv sered uchnivskoi ta studentskoi molodi: textbook / Zhuravel T. V., Samus V. V., Serheieva K. V., Soloviova O. D., Stroieva N. M.; ed. by Zhuravel T. V. Kyiv: FOP Buria O.D., 2014. 96 p.

18. Hendernochutlyvyi pidkhid u roboti z vrazlyvymy verstvamy naselennia u sotsialno-pravovii sferi: textbook / Anholenko V. V., Rasskazova O. I., Tkachenko M. Ye. et. al.; ed. by Otroshko T. V. Kharkiv: KhHPA, 2017. 78 p.

19. Mohylka O., Filenko I. Navchalna prohrama zi zmenshennia shkody vid naslidkiv ryzykovanoi povedinky pidlitkiv. Kharkiv, 2019. 59 p.

Received date 20.12.2019

Accepted date 20.01.2020

Published date 30.01.2020

Oleksandr Mohylka, Postgraduate Student, Department of Social Work and Social Pedagogy, Municipal Institution "Kharkiv Humanitarian-Pedagogical Academy" of Kharkiv Regional Council ,Rustaveli lane, 7, Kharkiv, Ukraine, 61001, Head of Center, Compass Day Care Center of the Blagoevsk Charitable Foundation, Velyka Panasivska str., 7, Kharkiv, Ukraine, 61052

E-mail: globus25@ukr.net

Marina Tkachenko, Postgraduate Student, Department of Social Work and Social Pedagogy, Municipal Institution "Kharkiv Humanitarian-Pedagogical Academy" of Kharkiv Regional Council, Rustaveli lane, 7, Kharkiv, Ukraine, 61001

E-mail: kh_juven@ukr.net 